\begin{tabular}{|c|c|c|}
\hline $\begin{array}{c}\text { OPEN } \\
\text { JOURNAL } \\
\text { SYSTEMS }\end{array}$ & Available on line at Directory of Open Access Journals & $\begin{array}{c}\text { Journal of } \\
\text { Hyperspectral } \\
\text { Remote Sensing }\end{array}$ \\
\hline ISSN:2237-2202 & & www.ufpe.br/jhrs \\
\hline
\end{tabular}

\title{
Airborne Laser Scanner: principles of operation, recent uses in Brazil and regulatory issue from laws and parameters in Brazil and in the USA
}

\author{
Carlos Henrique Sopchaki *, Tony Vinicius Moreira Sampaio ${ }^{* *}$ \\ * Doctor on Geography, Federal University of Paraná (UFPR), Laboratory of Spatial Patterns Analysis and Thematic \\ Cartography (LAPE-CT), Av. Cel. Francisco Heráclito dos Santos, 100 - Centro Politécnico - Sala 204 - Edifício João José \\ Bigarella - CEP:81.531-980 - Curitiba - Paraná - Brasil. Email: csopchaki@ gmail.com (Corresponding author) \\ ** Professor of the Geography Department at Federal University of Paraná (UFPR). Email: tony2sampaio@ gmail.com
}

Received 15 September 2016; accepted 01 November 2016

\begin{abstract}
DEM generated from LIDAR are being increasingly used in various fields of science. Thus, this article presents a review of the operation of the LIDAR and makes a survey of some recent research using that product in Brazil in order to identify methodologies for assigning spatial resolution of the survey and also the DEM. Also has been approached issue of standards and legislation for assigning spatial resolution both for the survey conducted via Airborne Laser Scanner, as for the Digital Elevation Model generated from the survey. The results showed that in Brazil, there is no standardized procedure with regard to the allocation of spatial resolution and is no shortage of laws and norms that regulate the activity in the country, unlike other countries with several regulatory documents in this area.
\end{abstract}

Keywords: LIDAR, digital elevation models, spatial resolution, Brazilian cartographic accuracy standards.

\section{Introduction}

Digital Elevation Models (DEM) generated from interferometry LIDAR (Light Detection and Ranging) have been used in various branches of knowledge, especially to obtain topographic attributes.

Products generated from the LIDAR are applied in environmental assessments, risk assessments, urban planning, mining, telecommunications network planning and energy, as well, as in research involving forestry, agriculture, among others (Bater and Coops, 2009; Giongo et al., 2010; Aguilar et al., 2010).

In addition the LIDAR denomination (Light Detection and Ranging) are also found others in literature, such as ALS (Airborne Laser Scanning) LADAR (Laser Detection and
Ranging), Profiling System Laser, Laser Scanning Systems (Brandalize, 2004).

According to Flood (2001), the theory about the LASER (Light Amplification by Stimulatied Emission of Radiance) was established in 1958. According to the author, during the 1960s and 1970s several experiments demonstrated the potential use of laser for sensing remote.

According Brandalize (2001), until the mid-1990s there was only one company selling laser profiling systems, but in 2000 there were more than five manufacturers and over 40 systems operating worldwide.

According to Schafer and Loch (2005) there are three main periods in relation to applications involving laser: laser was initially used almost exclusively by NASA; a second 
period there was a decline in prices and the laser entered the commercial market, but with limited capabilities, and finally in the mid-1990s, there have been advances in laser technology and traditional aerial survey companies began to purchase the system.

Rivas and Brito (2003) and Giongo et al. (2010) state that among the laser advantages are the possibility of having a considerable mass of data representative of the earth's surface, from which DEM can be generated using less working time compared to other methodologies.

Marks and Bates (2000) emphasize that LIDAR systems allow survey workflow areas up to 90 square kilometers in less than an hour.

As Sumerling (2011), the ability to capture points of the earth's surface at high resolutions is the main advantage of Airborne Laser Scanner over other remote sensing systems, for creating DEM.

The time savings to generate DEM, coupled with the increasing availability of Airborne Laser Scanner systems and high resolutions, makes this product is increasingly used in studies involving the terrestrial relief, especially in areas that require cartographic bases detail scale, such as forest surveys, geotechnical, environmental risk assessment, road planning, among others.

Thus, this article aims to make the survey of some recent research using LIDAR in Brazil, seeking to identify methodologies for assigning spatial resolution of the survey and also the DEM.

It will also examining the issue of Brazilian and US standards for assigning spatial resolution for both the survey carried out via Airborne Laser Scanner, as for the Digital Elevation Model generated from the survey.

\section{Operating principles of airborne laser scanner}

According to Brandalize and Philips (2002a), two events supported the invention of the laser: Albert Einstein's suggestion, in 1917, on the stimulated emission of light radiation; and the invention of the MASER (Microwave Amplification by Stimulation Emission of Radiation) in 1954, which occurred from the research developed during World War II involving RADAR (Radio Detection And Ranging).

The LIDAR is based on the same principles RADAR system, however, instead of radio waves, using laser pulses to locate the objects of interest, operating in the visible region, infrared and ultraviolet (Brandalize and Philips, 2002a, 2002b; Giongo et al., 2010).

Andersen et al. (2006) state that the LIDAR is an active sensor, because it has its own power source, the laser, which operates with electromagnetic radiation shortwave (between $1 \mu \mathrm{m}$ and $10 \mu \mathrm{m})$, being sensitive to atmospheric disturbances.

According to Antunes (2001), the operating principle of lidar is based on the use of a bundle that is emitted towards the object. Upon reaching the surface, this bundle is reflected and some portion returns to the system. From the return signal strength it is possible to derive information about the nature of the object's surface, but according to the author, the most relevant data is the time between the emission and the return of the bundle, as it allows to calculate the distance between the sensor and the object.

According to Giongo et al. (2010), an Airborne Laser system is basically composed of: a laser measurement unit, which transmits and detects the reflected pulse, recording the time between the time of transmission and the return; one Inertial Navigation System (INS), responsible for calculating the inclination of the sensor in three directions; GPS navigation systems, arranged in the aircraft and also on land (base stations) (Figure 1).

To Negrón (2002) and Brandalize (2004), in addition to the aforementioned components, a Laser System Airborne also features: control unit, which in addition to being responsible for energy and data recording also includes the operator interface; a processing unit used both in the planning stage as the postprocessing of data and; a scanning unit.

Regarding the scanning unit, also known as scanner, it is noteworthy that, according Brandalize (2004), is the unit responsible for the deflection of laser pulses. Schimalesky (2007) calls attention to the fact that the deflection movement provides a coverage range, not just a line along the moving direction of flight, wherein the beam is directed 
transversely to the displacement platform (Figure 2).

The LIDAR scan patterns (standard as measured points are distributed on the ground), according to Schimalesky (2007), vary according to the principle used by the scanner, the most common being the saw tooth pattern, elliptical pattern and parallel pattern (Figure 3).

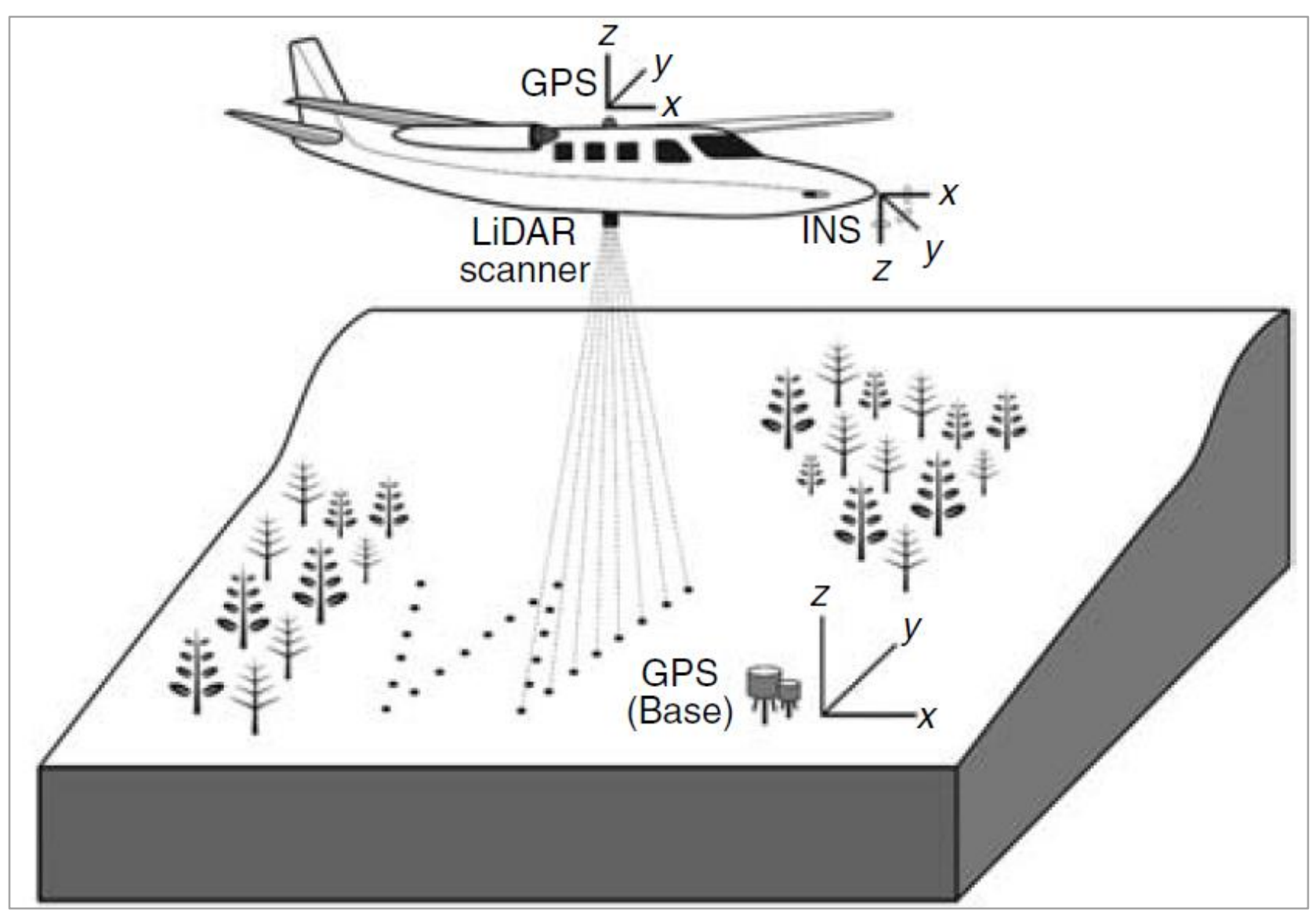

Figure 1 - Principles and components - Airbone Laser System. Source: Hetherington (2010).

Regardless of the scan pattern adopted by the Airborne Laser system is necessary to emphasize that, according Baltsavias (1999), the point density varies depending on the speed of the aircraft, repetition frequency of the pulses, the scan angle and height flight.

The author also states that the projection of the laser on the surface (footprint) does not occur in the form of point, but in the form of an ellipse, which is usually simplified, during the post-processing for a circle. This phenomenon is due to the deviation of the pulse, called by some authors IFOV (Instantaneous Field of View).
The diameter of the laser projection surface varies, therefore, depending on the height of the flight and the laser divergence angle (Figure 4).

According Brandalize (2001), the pulse divergence is a physical characteristic of the laser, which diverges as it propagates. However, the author states that this divergence is low compared to altitudes of flights. The author illustrates that a particular model of LIDAR, flying at an altitude of $1,200 \mathrm{~m}$, projecting a high deviation pulse would have a projection on the ground of $1.20 \mathrm{~m}$, and for a low divergence pulse projecting in the soil would be $0.24 \mathrm{~m}$. 


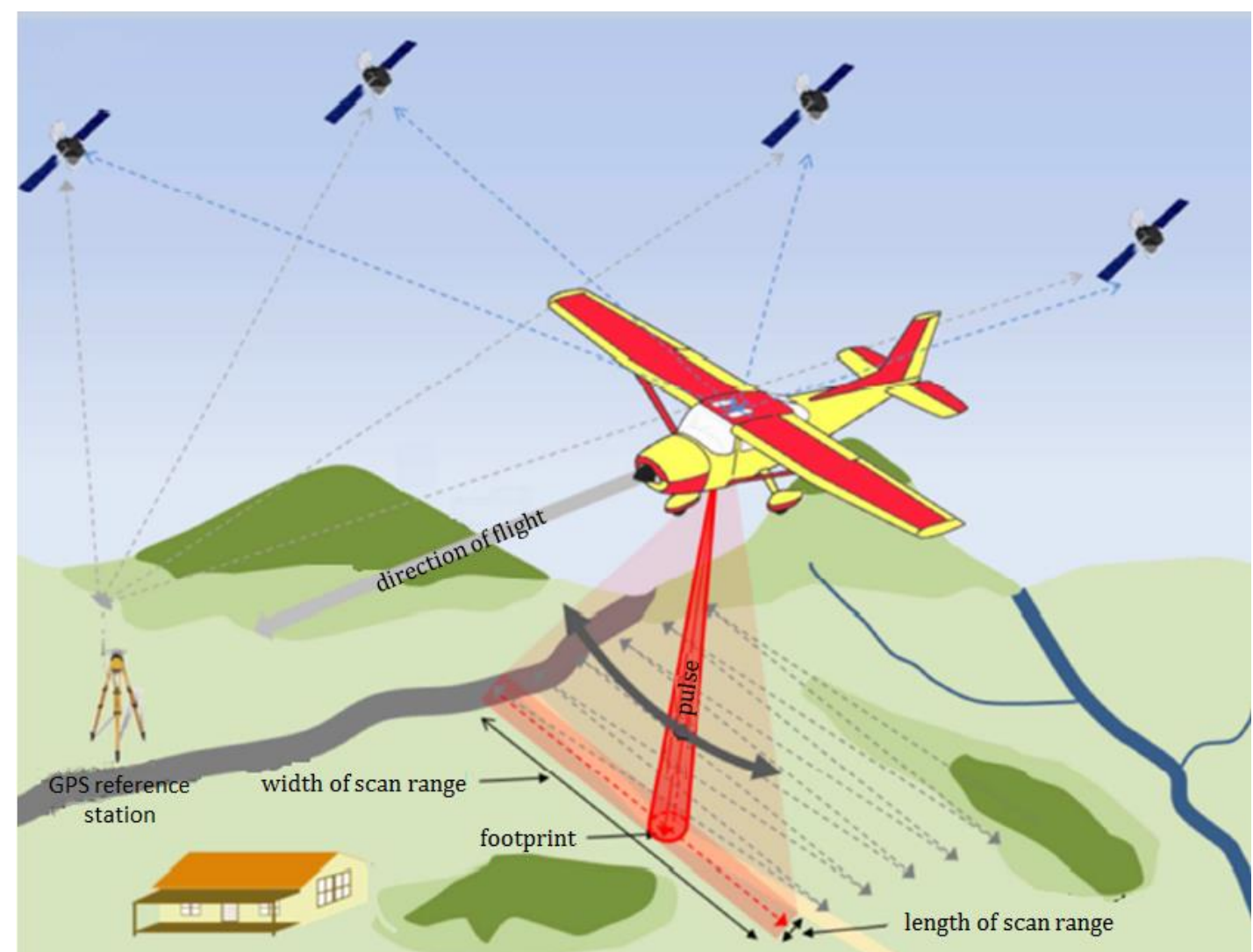

Figure 2 - Airborne Laser - cross bundle to the line of flight. Source: Pereira et al. (2013), adapted by the author (2015).

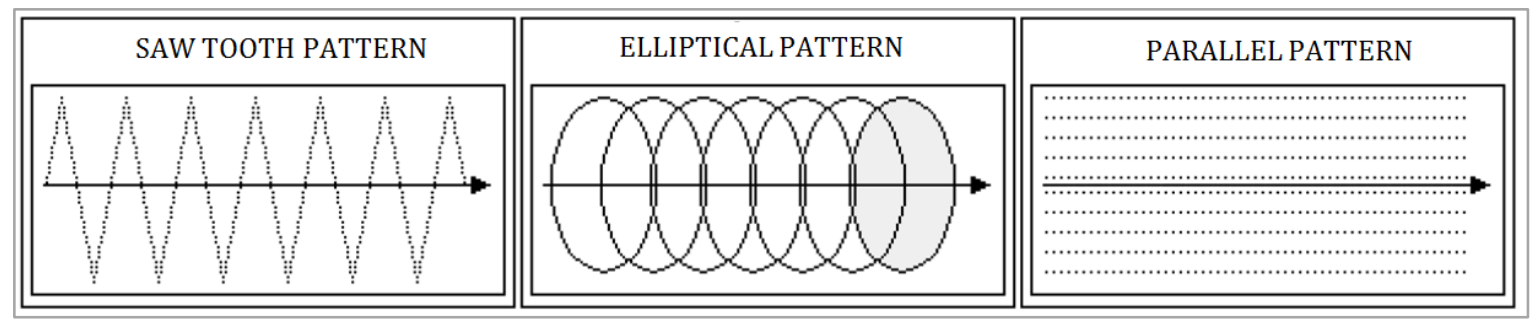

Figure 3 - Scanning Patterns. Source: Brandalize (2004), adapted by the author (2015).

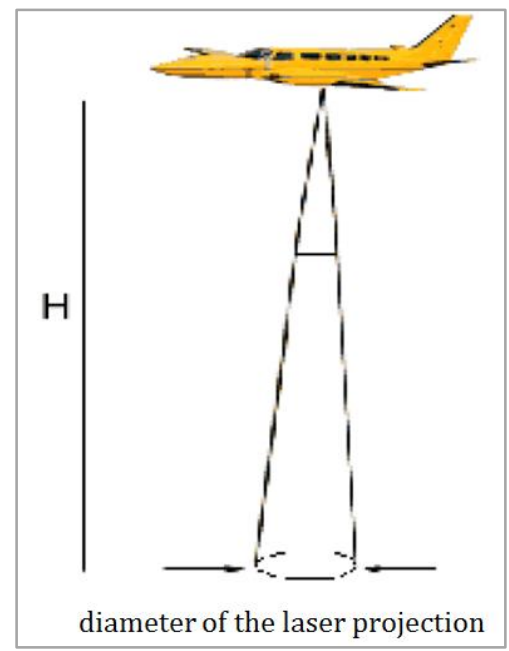

Figure 4 - Point diameter projected in the ground as a function of flight height. Source: Brandalize (2001), adapted by the author (2016). 
Schimalesky (2007) states that, due to the diameter of the projected point on the ground, the sensor can register more than one surface to the same pulse as the surface of the ground and other structures (natural or artificial) arranged on the ground.

In this sense, several authors (Fowler, 2001; Brandalize, 2004; Centeno and Mitishita, 2007; Giongo et al., 2010; and others) discuss about the capacity of the sensors to record multiple returns for each laser bundle emitted. Giongo et al. (2010) state that the first laser was developed with pulse systems (discrete echo), which recorded the first and last return of pulses and some intermediate pulses. According to the authors, most recently, a new generation of laser systems has been developed, known as continuous wave system (full waveform), which record all the pulse signal (Figure 5).

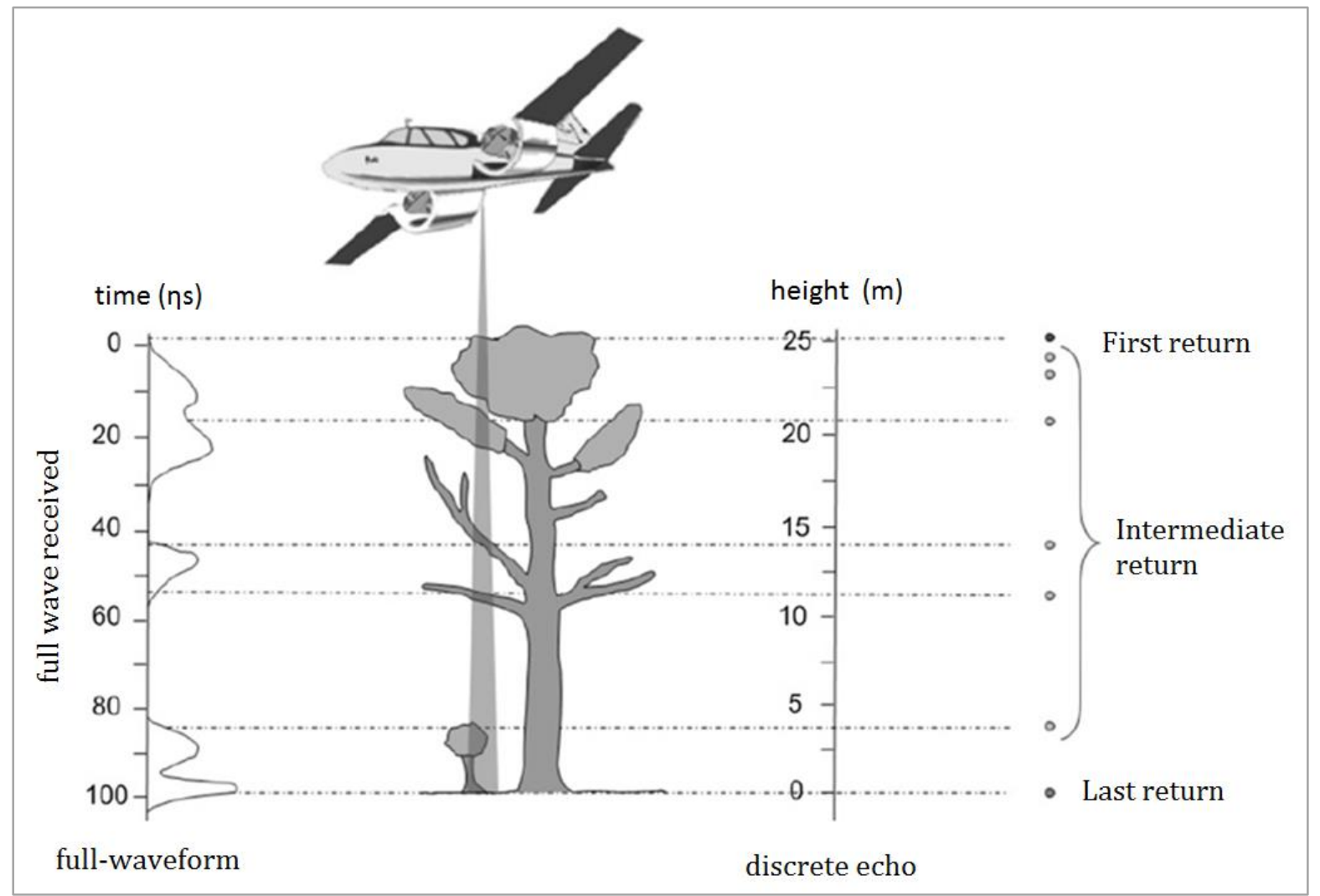

Figure 5 - The different systems laser airborne - full-waveform and discrete echo. Source: Giongo et al. (2010), adapted by the author (2015).

As explained previously it was not intention of this article to establish an exhaustive review on the functioning of the Airborne Laser System. For further information it is recommended to consult other authors, such as Baltsavias (1999), Brandalize (2001), Brandalize (2004), Centeno and Mitishita (2007), Heritage and Large (2009), Giongo et al. (2010), among others.

\section{Recent applications involving airborne laser scanner in Brazil}

There is a growing use of surveying made from the Airborne Laser Scanner in research in Brazil. A quick survey done in the annals of Simpósio Brasileiro de Sensoriamento Remoto - SBSR (Brazilian Symposium on Remote Sensing), since the event organized in 1998 to the most recent (2015) shows the growth trend in the use of Airborne Laser Scanner.

The first paper on the subject appeared in the XI SBSR, in 2003. The next event (XII SBSR - 2005) a specific axis was created to address the issue, which was entitled "Analysis and LIDAR application", with six papers published. This axis was kept for two more 
events: 2007, with 11 published articles and 2009, with 8 published articles. In 2011 research involving LIDAR were incorporated into other subjects, the axis entitled "Cartography, Photogrammetry, LIDAR and Sensors", and accounted for 16 of the papers published in SBSR that year. But the next SBSR (2013) work involving LIDAR again got its own axis, under the heading "LIDAR: Sensors and Applications" and totaled 20 publications. The XVII SBSR, which occurred in 2015 (most recent event to the closing date of this article), maintained its own axis of LIDAR, which were published 18 papers, and other four studies using LIDAR, but were published in other axes, totaling 22 articles (Figure 6).

In addition to the publications available at events like the SBSR, it is increasingly common to find dissertations, doctoral theses and papers published in scientific journals. Outstanding among these publications, research involving forest and vegetation variables, which represent the largest amount of research involving Airborne Laser in Brazil.

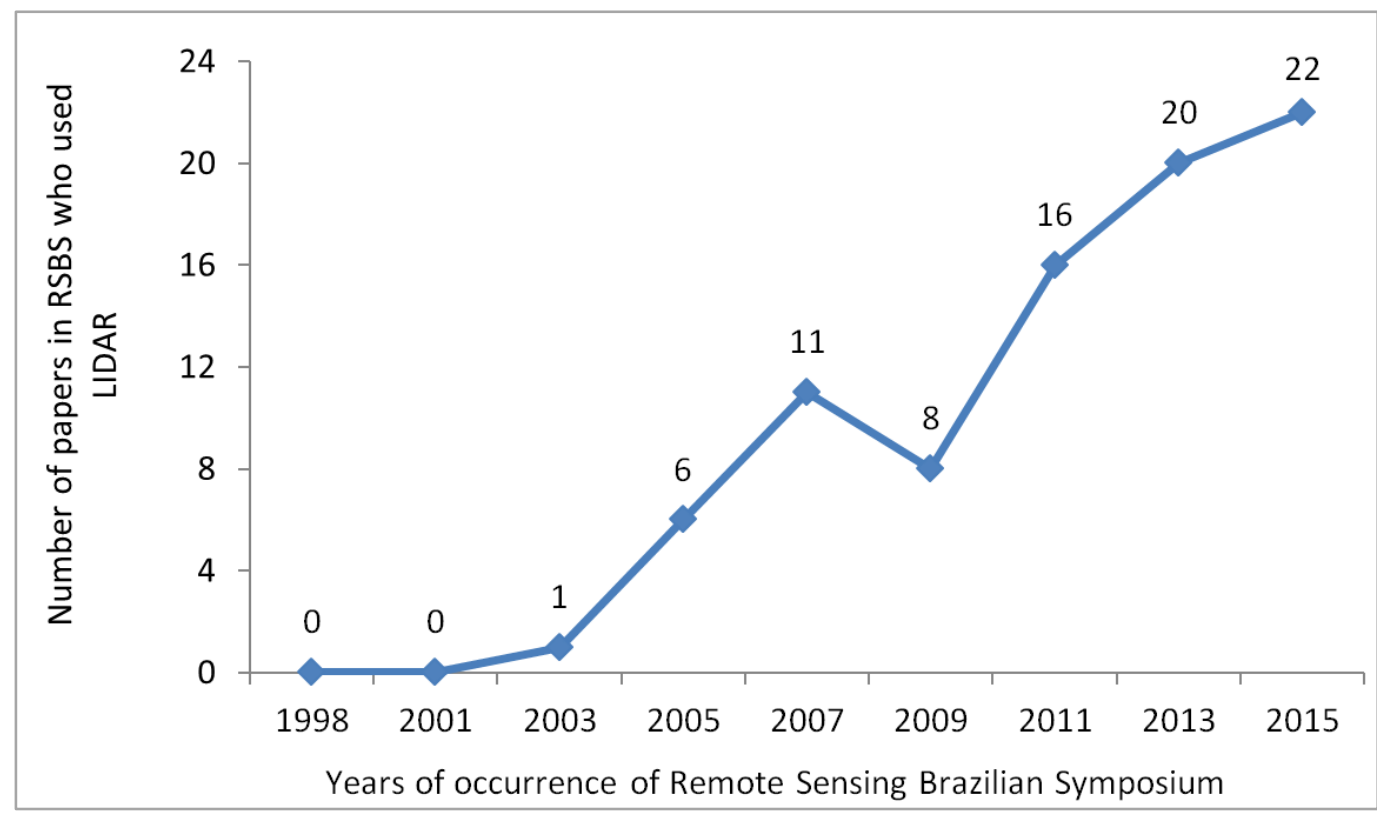

Figure 6 - Publications graph involving LIDAR in Remote Sensing Brazilian Symposium (1998-2015). Source: SBSR (2015), organized by the author (2016).

In general terms it can be said that research involving forest cover work with a methodology that is to develop the Digital Elevation Model (model covering beyond the surface objects on it arranged, whether natural or artificial) and the Digital Terrain Model (model representing the terrain itself, disregarding the objects arranged on the surface). So it proceeded subtracting a model for the other, the result being the height of the trees. It is inferred, therefore, that both models should be capable of representing the surface and the ground, respectively, with a high degree of detail and accuracy.

Giongo et al. (2012) conducted a study to estimate the height of the base of the trees in an area of the city of Curitiba. According to the authors, the projected point on the ground (footprint) by Airborne Laser Scanner was 0.27 $\mathrm{m}$ in diameter, but the authors did not mention that the density of points.

A LIDAR survey with a density of 0.99 points per square meter was used by Ribas and Elmiro (2013) to calculate the area of native tree tops in the Ecological Station of the Federal University of Minas Gerais in Belo Horizonte.

Research involving volume estimation of Eucalyptus sp trees was conducted by Carvalho (2013), in São Luis do Paraitinga. LIDAR data used for the survey had, according to the author, density of 5 points per square meter and spatial resolution of $0.5 \mathrm{~m}$.

In order to identify patterns of isotropy and anisotropy in the estimated height of Eucalyptus plantation, Alvarez et al. (2013) used point cloud obtained via Airborne Laser Scanner 
with 6 points per square meter density and generated DTM with a resolution of $1 \mathrm{~m}$, which, according to the authors, was based "on the average value of the points classified as ground".

In addition to several research involving the study of vegetation, more recently, other areas of knowledge began to use more often LIDAR products to obtain topographic attributes. Among these stand out areas such as geotechnical, environmental analysis and risk assessment.

Daru et al. (2013) used LIDAR product with an average density of 1 point per square meter in order to carry out a topographic survey in the region of the hydroelectric power plant Barra do Brauna to provide support for a study on Emergency Action Plan in the region. The authors state that obtained "precision and high accuracy with the model" - $15 \mathrm{~cm}$ for altimetry, and $50 \mathrm{~cm}$ for planimetry.

Becker and Centeno (2013) conducted a review of cloud filtering methods points to generation DTM in an area in the town of São José dos Pinhais. According to the authors, the survey obtained from LIDAR had density of 1 point every $0,53 \mathrm{~cm}$.

An evaluation of the modeling of runoff in urban areas was done by Pereira (2013) from LIDAR surveying with resolutions of $0.5 \mathrm{~m}$ and $0.7 \mathrm{~m}$.

Some research (Schuch and Loch, 2012; Geissler, 2012; Fazan and Dal Poz, 2010; Ribeiro Junior and Vieira, 2013) do not mention the density points of the survey carried out from the Airborne Laser Scanner.

Schuch and Loch (2012) elaborated study on the variation of fractal drainage network using standard Airborne Laser Scanner data. Although the authors have not informed which the density lifting points, they mentioned that the model had accuracy of $4 \mathrm{~m}$.

In order to develop a study assessing flood scenarios in the town of Joinville, Geissler (2012) used NTM developed from a survey conducted by Airborne Laser Scanner that, according to the author, had spacing of $20 \mathrm{~cm}$ between the contour lines.

Fazan and Dal Poz (2010) presented a method to predict and compensate for shadows of buildings in high-resolution images with the help of DSM generated from LIDAR.
Ribeiro Junior and Vieira (2013) used survey come from Airborne Laser Scanner to calculate Mineral volume stockpiled using the Analytic Hierarchy Process.

From this short review of recent studies using products from the Airborne Laser Scanner, it appears that there is still a lack of standardization with regard to scale, spatial resolution, point density and accuracy of such models.

Several authors have just not mentioning in their studies some of the terms mentioned in the previous paragraph. When analyzing some publications it is clear that there is a discrepancy, since studies with similar goals have LIDAR products with different resolutions, such as the four studies presented involving vegetation.

Giongo et al. (2012) did not report the density of the dots, however, to counteract the work Ribas and Elmiro (2013) for the Oak (2013), it is noted that a survey had a resolution around 5 times higher than the other. While Ribas and Elmiro (2013) used LIDAR with a density of 0.99 points per square meter, Carvalho (2013) used LIDAR with a density of 5 points per square meter.

Alvares et al. (2013) and Carvalho (2013) worked with estimated height of Eucalyptus sp. Although the density points were lot like (5:06 points per $\mathrm{m} 2$, respectively), the authors generated DTM with resolutions that differed by $100 \%: 1 \mathrm{~m}$ and $0.5 \mathrm{~m}$, respectively.

Briefly it can be said that the data application of LIDAR goals in research have similar purpose, which is to carry out a topographic survey on the level of detail to, from it, infer other attributes inherent to the specificity of each study (height vegetation, topographical attributes, drainage flow, etc.). However, the methods adopted for both the laser survey pattern, and for the generation of the DEM / DTM have shown inconsistencies.

Therefore, it is necessary to further deepening on questions of scale, spatial resolution, point density and accuracy of surveying, so that the final results of the work are not prejudiced.

\section{Spatial resolution, parameters and standards}


The spatial resolution, according to Meneses and Almeida (2012), is an important property of an image because it determines the size of the smallest object that it can be identified. The authors state that, by definition, an object can only be detected when the size of this is at least equal to or greater spatial resolution image. However, the authors draw attention to the fact that, "in practice", the spatial resolution should be at least half the size of the measured object, so that this is identified in the image.

Antunes (2001) states that the spatial resolution corresponds to the land area represented by one pixel in the image. According to the author, the smaller the pixel further details can be seen in the image, so the higher the resolution.

In this sense, a priori, surveyings made from Airborne Laser Scanner do not have spatial resolution, so there is no direct relationship between pixel size and / or size of the smallest object that can be identified in the image, but certain density projected points on the ground. However, the relationship must be established in the planning stages and flight, relates mainly to the relationship between the angle of divergence and the height of the flight. For greater height and divergence angle of the sensor, the greater will also be the projected footprint on the ground. In this case, objects smaller than the diameter of the footprint turn being masked.

Boehler et al. (2002) state that the resolution of the laser sensor is associated with its ability to detect small objects or parts of objects in the point cloud. According to the authors, two factors contribute to this capability: the smallest possible increment of the angle between two successive points and the size of the laser beam projected on the object.

In general, the density and the spacing between the points and the diameter of the footprint will be paramount parameters and benchmarks for the generation of Digital Elevation Model for post processing. Therefore, these parameters should be adjusted according to the purpose of the research, the standard of relief and vegetation.

There are other parameters intrinsic to the operation of laser sensor that should also be taken into account during the flight planning stage as they may influence the resolution obtained by the equipment. Among these are: angle, frequency and sweep pattern, frequency of Inertial Navigation System, GPS frequency, laser pulse frequency, width of the scan range, number of dots per line scanned; and the model of laser measurement unit (discrete-echo or fullwaveform). More details about these parameters can be found in Negrón (2002), Brandalize (2004) and Giongo et al. (2010), among others.

After the data acquisition stage, it is necessary that the point cloud is transformed into a digital elevation model. It is even challenging task, it is necessary to transform a dense point cloud to an array in raster format without losing quality as well, so do not overload any resources (human, software, hardware) in order to avoid unnecessary expenses, both temporal, as financial.

Sangster (2002) states that dense data clouds can enable the representation of the land in great detail, but the author draws attention to the fact that, on the other hand, there is a significant increase in the volume of data, imposing challenges for the storing, processing and manipulation of such data.

The researcher will have to take decisions concerning the reduction or absence of cloud density of laser points (more information on Liu, 2008), choosing the most appropriate interpolation and what resolution will be applied to the matrix grid.

In this sense, Lillesand and Kiefer (2000) state that the grid resolution controls many aspects of the generated model. According to the authors, the characteristics of the objects being mapped (number of objects, area, medium size, perimeter of objects) vary according to changes the spatial resolution.

Liu (2008) states that the determination of the resolution of the Digital Elevation Model is currently the central problem for generation of the DEM and spatial analysis.

Pike (2002) states that even methods considered advanced as LIDAR do not guarantee quality for the DEM and that all DEMs obtained by these processes have errors, some of them serious.

Likewise et al. (2002) draw attention to this problem. According to the authors, such as laser scanning sensors reached a high technological level, the focus must turn to the development of algorithms for extracting 
information from the dense cloud of vector points.

However, there are few studies that propose methods to generate the DEM and assignment of spatial resolution. Among them stand out McCullagh (1988), Wack and Wimmer (2002) and Hengl (2006).

McCullagh (1988) suggests that the number of grid cells is approximately the same as the number of projected points on the ground (point cloud), namely the resolution of DEM be directly related to the density of the cloud of points. According to the author, the grid size can be calculated from the following equation (Eq. $1)$ :

$$
S=\sqrt{\frac{A}{n}}
$$

Where $n$ equals the number of points projected on the ground and $A$ is equivalent to the land area.

Following the same trend that the number of grid cells should be similar to the number of cloud points, Wack and Wimmer (2002) quoted in Pacheco et al. (2011) propose an algorithm to assign each grid cell in a point of the 3D cloud, however, it is unclear how the methodology authors reach the value of spatial resolution, but only as attribute values to cells, as represented by the following equation (Eq. 2):

$$
\operatorname{lin}=\frac{N_{\max }-N}{\operatorname{Res}} \text { e } \operatorname{col}=\frac{E-E_{\min }}{\operatorname{Res}}
$$

Where lin is equivalent to grid line, col refers to the grid column, $N_{\max }$ refers to the coordinate of the far north, $E_{\min }$ refers to coordinate the extreme eastern and Res to the spatial resolution of the grid.

Hengl (2006) proposes several methods to assign value to spatial resolution, however, applies to none product obtained through laser interferometry, in which a dense cloud point needs to be transformed into a matrix product.

It appears, therefore, that there is a lack of studies involving the allocation of spatial resolution for the matrix grid generated from the cloud of LIDAR points, causing thus a methodological deficiency and consequent lack of standardization in this phase of the work and of research.

Associated with this methodological shortage, there is in Brazil, certain normative disabilities to regulate issues concerning work involving LIDAR, such as relative density points and angle of divergence, scanner resolution, spatial resolution of DEM generated, among others.

The aerial surveys conducted in Brazil must comply with the Decree-Law No. 1,177/71, which regulates aerial surveys in national territory; by Decree No. 2278 of July 17, 1997, which regulates the Decree-Law No. 1,177/71; and Ordinance 637/98 of the Defense Ministry, which deals with confidentiality of aerial survey data.

It notes that all three of these legal instruments are prior to the operation of the first Airborne Laser Scanner in Brazil, which, according Brandalize (2004), occurred in mid2001.

Even with regard to legislation, the cartographic documents produced in Brazil must comply with the Decree No. 89817 of June 20, 1984, which establishes the regulatory instructions of the technical standards of the national mapping and Cartographic Accuracy Standard (PEC) (Figure 7).

Several authors (Rivas and Brito, 2003; Brandalize, 2004; Cavassin Junior, 2004; Cavassin Junior et al., 2005; Slodoba, 2005; Cruz et al., 2011) showed that the surveys made from Airborne Laser Scanner fulfill the Cartographic Accuracy standards for Class a, including scales larger than 1: 5,000.

But the Brazilian Cartographic Accuracy Standards, by being inserted in a decree of the mid-1980s, does not directly address digital cartography, but analog maps. Dalmolin and Leal (2001) state that the Cartographic Accuracy Standards are not covered procedures for evaluation of digital cartography, because, according to the authors at the date of its publication, few were the experiences recorded in this area. 


\begin{tabular}{|c|c|c|c|c|}
\hline & \multicolumn{2}{|c|}{ Planimetry } & \multicolumn{2}{|c|}{ Altimetry } \\
\hline & $\begin{array}{c}\text { Standard } \\
\text { Cartographic } \\
\text { Accuracy } \\
\end{array}$ & Standard Error & $\begin{array}{c}\text { Standard Cartographic } \\
\text { Accuracy }\end{array}$ & Standard Error \\
\hline Class A & $\begin{array}{l}0,5 \mathrm{~mm} \text { in the map } \\
\text { scale }\end{array}$ & $\begin{array}{l}0,3 \mathrm{~mm} \text { in the map } \\
\text { scale }\end{array}$ & $\begin{array}{c}1 / 2 \text { of equidistance } \\
\text { between the contour lines }\end{array}$ & $\begin{array}{l}1 / 3 \text { of equidistance } \\
\text { between the contour lines }\end{array}$ \\
\hline Class B & $\begin{array}{l}0,8 \mathrm{~mm} \text { in the map } \\
\text { scale }\end{array}$ & $\begin{array}{l}0,5 \mathrm{~mm} \text { in the map } \\
\text { scale }\end{array}$ & $\begin{array}{c}3 / 5 \text { of equidistance } \\
\text { between the contour lines }\end{array}$ & $\begin{array}{l}2 / 5 \text { of equidistance } \\
\text { between the contour lines }\end{array}$ \\
\hline Class C & $\begin{array}{l}1,0 \mathrm{~mm} \text { in the map } \\
\text { scale }\end{array}$ & $\begin{array}{c}0,6 \mathrm{~mm} \text { in the map } \\
\text { scale }\end{array}$ & $\begin{array}{c}3 / 4 \text { of equidistance } \\
\text { between the contour lines }\end{array}$ & $\begin{array}{l}1 / 2 \text { of equidistance } \\
\text { between the contour lines }\end{array}$ \\
\hline
\end{tabular}

Figure 7 - Classification of maps according to the Cartographic Accuracy Standard. Source: Brazil (1984), organized by the author (2014).

In this sense, Sopchaki (2016) questions how to check altimetry accuracy of digital cartographic products using the parameter set by the Cartographic Accuracy Standards, a measure established relationship with equidistance among the contour lines, since digital cartographic products do not necessarily have such contour lines. The author also recommends that the standard should be revised and updated in order to include specific parameters to evaluate the accuracy of digital cartographic

Leal (2007) makes a number of recommendations to be implemented in the evaluation of the quality of Brazilian cartographic products, including the updating Decree No. 89,817 / 84, which deals with the Cartographic Accuracy Standards and recommends also include components of quality for the digital cartographic product.

Likewise, Santos et al. (2010) corroborate the assertion that the Cartographic Accuracy Standards does not include the mapping generated by digital processes and point to the need to create a systematic procedure for evaluation of these cartographic products.

In this sense, although the Cartographic Accuracy Standards continues to be used as a parameter to measure quality cartographic products generated from digital cartography, it appears that there is no appropriate legal instrument to carry out such measurements in Brazil. It is noteworthy that in this framework are framed the surveys made from Airborne Laser Scanner. Also, besides there is no specific legislation that addresses the surveying made with Airborne Laser Scanner, there are no parameters or guidelines in the country, coming from government agencies, non-governmental agencies, associations, among others, that could guide work involving LIDAR.

On the other hand, in other countries there are records in this direction, particularly in the United States. In that country there are publications of various actors involved in the use of Airborne Laser Scanner, focusing on the development parameters and standards.

Among the major agencies and programs that work directly with respect to US guidelines about LIDAR include: Federal Geographic Data Committee (FGDC), Federal Emergency Management Agency (FEMA), U.S. Army Corps of Engineers (USACE), National Oceanic and Atmospheric Administration (NOAA), U.S. Geological Survey (USGS), National Digital Elevation Program (NDEP) e American Society for Photogrammetry and Remote Sensing (ASPRS).

According to NOAA (2012) four primary documents has helped the development of surveying conducted with Airborne Laser Scanner that country: National Standard for Spatial Data Accuracy (FGDC, 1998), Guidelines for Digital Elevation Data (NDEP, 2004), ASPRS Guidelines: Vertical Accuracy Reporting for Lidar Data (ASPRS, 2004) e Procedure Memorandum $\mathrm{N}^{\circ} 61$ - Standards for Lidar and Other High Quality Digital Topography (FEMA, 2010). However, beyond these documents are also used: Engineering and Design - Photogrammetric Mapping (USACE, 2002), Light Detection And Ranging (LIDAR) Requirements - Scope of work for shoreline 
mapping (NOAA, 2004), ASPRS Lidar Guidelines: Horizontal Accuracy Reporting (ASPRS, 2005) e Lidar base specification version 1.0 - USGS (Heidemann, 2012).

It should be noted therefore that, unlike Brazil, where there is a shortage of rules and parameters about LIDAR, that country is the reverse, there are several documents trying to regulate the surveys made from Airborne Laser Scanner. In this sense, ASPRS (2005) claims to be having a job involving different professionals and companies that work with LIDAR survey, as well as various organs and programs (such as FEMA, USACE, NOAA, USGS, ASPRS, NDEP, FGDC) in order to develop common guidelines for using Airborne Laser Scanner.

Although there are various standards and reference documents on the subject in the United States, and most of them have already been drafted in the twenty-first century, some authors (Schuckman, 2014; Graham, 2014) discuss about procedures adopted by some standards to evaluate the accuracy of models as well as the fact that the vertical accuracy be at the center of attention, to the detriment to the horizontal accuracy of the models. Schuckman (2014) criticizes the use of contour lines as standard of accuracy in digital models. The author states that the LIDAR generates a digital model as a primary product, and the contour lines, at best, derived from second or third order of this product. Schuckman (2014) draws attention also to the fact that a paradigm shift has been made in terms of accuracy of definition regardless of an interval between contour lines.

That said, it is noteworthy that due to the vast amount of laws, rules and regulations US, this research will weave some brief comments only on the National Standard for Spatial Data Accuracy - NSSDA (FGDC 1998) and a document that bring specific parameters for the LIDAR, in this case, one of the most recent, Lidar base specification version 1.0 - USGS (Heidemann, 2012).

The National Standard for Spatial Data Accuracy - NSSDA would be broadly equivalent in Brazil by Decree No. 89,817 / 84 (which deals with the Cartographic Accuracy Standards). However, the NSSDA differs from Brazilian decree, in the sense that succeeded the National Map Accuracy Standards (NMAS, 1941) since 1998, as this because it was produced in the early 1940s and have suffered only two revisions in 1943 and 1947, it dealt only accuracy standards based on analog cartography.

NMAS was focused on the validation of paper maps and no digital data, so NSSDA helped overcome this obstacle by providing method for checking the quality of spatial data both in digital form, as in print (Minnesota Planning, 1999).

Regarding the vertical accuracy, NMAS (U.S. Bureau Of The Budget, 1941) stated that $90 \%$ of points should have smaller errors than half the contour interval of contour lines.

Briefly, it can be said that the NSSDA evaluates the accuracy by using the Mean Squared Error, admits an accuracy of at least 95\% and defined as needed for the test at least 20 well-defined points, which may not have been used for generation of cartographic databases or digital models of the terrain representation. The justification for this sample size is that when 20 points are tested, the $95 \%$ confidence level allows one of these points exceeds the limit stated in the specifications of the accuracy of the product (FGDC, 1998; Minnesota Planning, 1999).

More detailed information should be sought from the document itself (FGDC 1998) and also in Rocha (2002) and Smith (2010). A guidebook explaining the entire application can be obtained in Minnesota Planning (1999).

The LIDAR based specification version 1.0, the USGS (Heidemann, 2012) is perhaps the most recent reference, in the case of parameterization for Airborne Laser Scanner in the United States. The document follows basically the accuracy standards of NSSDA and Guidelines for Digital Elevation Data (NDEP, 2004), introducing concepts and LIDAR's own parameters.

In this document, it is observed that is used as a parameter by the USGS, the term nominal pulse Spacing (NPS), a common measure of density of a laser set data, which in dense point clouds may be expressed in dots per square meter. The following are some considerations present in the document about the NPS:

- You need at least 1 point per $2 \mathrm{~m}$;

- Depending on the terrain and land use, a higher density of points may be required in specific projects; 
- The target NPS for a project should not be achieved through swath overlap or multiple passes.

- The NPS (for lower densities) should be calculated as the square root of the average area per point.

With respect to the DEM generated from the point cloud, USGS, among other things, recommends that the cell size can not be greater than $3 \mathrm{~m}$, and can not be smaller than NPS. The document also states that the point cloud should be regular and in cases where this is not possible, the uniformity of the cloud should be evaluated using the following steps::

- Generate a grid with a density equal to 2 times the value of NPS using a radius equal to the projected into the NPS;

- To ensure that at least $90 \%$ of the cells of the grid containing at least one laser poni;

- The assessment should be made into individual ranges using only the first return points located in the central portion of each range;

- Excluded empty acceptable data according to the standard;

However, regarding this testing the standard also advises that:

- This uniformity test can be relaxed in rugged terrain areas, where it is impractical to maintain a consistent and uniform distribution.

It should be noted that, as stated earlier, the Lidar base specification version 1.0 (Heidemann, 2012) calls attention to the fact that the relief features may require a higher density of points in the survey made with LIDAR.

This inference is in agreement with the foregoing by Su and Bork (2006) and Guo et al. (2010), which showed the influence of land slope in MDTs generated from LIDAR, as well as Sopchaki (2016), which showed the influence of the relief characteristics in the quality of digital terrain models generated from sampling points with irregular grids (unsystematic), which, with respect to LIDAR, occur mainly in areas with coverage denser vegetable, as can be seen in Brandalize (2001), Rabbit and Vargas (2007) Schimalesky (2007).

Based on the above data, it is inferred that, although the standard does not contemplate a relationship between density points, footprint and spatial resolution laser survey, there is an attempt to establish minimum standards for both the flight stage, as to the DEM generation.

In this direction, this and other norms, laws and international standards could serve as a model for a discussion and update of the Brazilian legislation, including this aerial surveys of the services performed from Airborne Laser Scanner also seeking to establish parameters for scalar relationships between points density cloud and size of footprint, both the spatial resolution of the survey, as with the DEM to be generated.

\section{Conclusions}

This research aimed to survey some recent articles that used such a product in Brazil, seeking to identify methodologies for assigning spatial resolution of the survey and also the DEM.

It was found that there is a growing trend in the work published in Brazil involving the theme Airborne Laser Scanner, as found from a survey conducted together with the Brazilian Symposium Proceedings of Remote Sensing.

Regarding the research discussed in this article that used LIDAR, it was observed that there is a great number of publications in areas involving vegetation studies, however, other areas of knowledge which demand Digital Elevation Models in detail scale, such as geotechnics, environmental analysis, risk analysis and transport planning are also producing research with products obtained via Airborne Laser Scanner.

It is also inferred from the work shown here, that there is no standardization for spatial resolution assignment for both the stage of the survey, and for the stage of the generation of Digital Elevation Model. It is noteworthy also that the analysis was hampered due to the lack of methodological detail in many works.

This article also addressed the issue of standards and legislation for assigning spatial resolution for both the survey carried out via Airborne Laser Scanner, as for the Digital Elevation Model generated from the survey. 
It has been found that in Brazil there is no legislation that applies, and standards and benchmarks to regulate the activity involving Airborne Laser Scanner. It is noteworthy that the Brazilian Cartographic Accuracy parameters are the mid-1980s, and so does not include products generated from digital mapping.

On the other hand, in the US Territory, there are several laws, rules and regulations, as well as government agencies involved in regulation, seeking introduce parameters for work involving Airborne Laser Scanner. Unlike Brazil, the US Law and Standards include the products generated from digital cartography, however, although advance for the introduction of minimum standards for the flight and for the generation of the DEM, tend to not address the issue spatial resolution.

Finally, it is worth mentioning that recommends a broad and democratic debate in Brazil, involving the various actors engaged in work and research with Airborne Laser Scanner (State, aerial survey companies, professionals involved, government research and education, among others) to regulate, adjust parameters and create methodologies for the work and research are conducted within standards with excellence and quality.

\section{References}

Aguilar, F.J, Mills, J.P., Delgado, J., Aguilar, M.A., Negreiros, J.G., Pérez, J.L., 2010. Modelling vertical error in LiDAR-derived digital elevation models. ISPRS Journal of Photogrammetry and Remote Sensing 65, 103-110.

Alvares, C.A., Gorgens, E.B., Silva, A.G.P.da, Campoe, O.C., Rodriguez, L.C.E., Stape, J.L., 2013. Integrando Geoestatística e LIDAR para identificar padrões isotrópicos e anisotrópicos da altura de plantações de Eucalyptus grandis. III Simpósio de Geoestatística Aplicada em Ciências Agrárias.

Andersen, H.E., Reutebuch, S.E., Mcgaughey, R.J., 2006.A rigorous assessment of tree height measurements obtained using airborne lidar and conventional field methods. Canadian Journal of Remote Sensing 32, 355366.

Antunes, A.F.B., 2001. Fundamentos de Sensoriamento Remoto em Ambiente de
Geoprocessamento. CIEG/UFPR, Curitiba.

ASPRS, 2004. ASPRS Guidelines: Vertical Accuracy Reporting for Lidar Data. American Society for Photogrammetry and Remote Sensing. Available: http://goo.gl/6Kwl3H. Access: aug., 20, 2014.

ASPRS, 2005. ASPRS Lidar Guidelines: Horizontal Accuracy Reporting. American Society for Photogrammetry and Remote Sensing. Available: http://goo.gl/LpIrXJ. Access: aug., 20, 2014.

Baltsavias, E.P., 1999. Airborne Laser Scanning: Basic Relations and Formulas. ISPRS Journal of Photograx mmetry \& Remote Sensing 54, 199-214.

Bater, C.W., Coops, N.C., 2009. Evaluating error associated with lidar-derived DEM interpolation. Computers \& Geosciences, Volume 35, 289-300.

Becker, J.H., Centeno, J.A.S., 2013. Avaliação de métodos de filtragem de nuvem de pontos derivados do sistema laser scanner aerotransportado para obtenção de MDT. Revista Brasileira de Cartografia 65/4, 651659.

Boehler, W., Heinz, G., Marbs, A., 2002. The potential of non-contact close range laser scanners for cultural heritage recording. International archives of photogrammetry remote sensing and spatial information sciences 34, 430-436.

Brandalize, A.A., 2001. Perfilamento a LASER: comparação com métodos Fotogramétricos. XX Congresso Brasileiro de Cartografia.

Brandalize, M.C.B., Philips, J.W., 2002a. Laseres nos Levantamentos Terrestres. Revista InfoGeo 4, 52-55.

Brandalize, M.C.B., Philips, J.W., 2002 b. Padrões de classificação de equipamentos laser utilizados em levantamentos terrestres e aéreos. Geodésia Online-Revista da Comissão Brasileira de Geodésia 1, 1.

Brandalize, M.C.B., 2004. A Qualidade Cartográfica dos Resultados do Laserscanner Aerotransportado. Thesis (Doctoral). Florianópolis, UFSC.

BRASIL, 1971. Decreto-lei $n^{\circ} 1.177$, de 21 de junho.

BRASIL, 1984. Decreto $\mathrm{n}^{\circ} 89.817$, de 20 de junho.

BRASIL, 1997. Decreto ${ }^{\circ} 2.278$, de 18 de julho. 
BRASIL, 1998. Portaria $\mathrm{n}^{\circ}$ 637-SC-6/FA-61, de 05 de março.

Carvalho, S.deP.C.e, 2013. Estimativa volumétrica por modelo misto e tecnologia laser aerotransportado em plantios clonais de Eucalyptus sp. Thesis (Doctoral). Piracicaba, ESALQ.

Cavassin Junior, I., 2004. Utilização de dados derivados do varredor laser na geração de cartas planimétricas na escala 1:2000. Thesis (Master). Curitiba, UFPR.

Cavassin Junior, I., Centeno, J.A.S., Mitishita, E.A., 2005. Utilização de dados do varredor laser na cartografia urbana. Boletim de Ciências Geodésicas 11, 201-219.

Centeno, J.A.S., Mitishita, E.A., 2007. Laser scanner aerotransportado no estudo de áreas urbanas: a experiência da UFPR. XIII Simpósio Brasileiro de Sensoriamento Remoto 4, 3645-3652.

Coelho, A.H., Vargas, R.M.A., 2007. Geração de modelos digitais de terreno a partir de dados de laser scanner aerotransportado em área de floresta usando o software livre GRASS. XIII Simpósio Brasileiro de Sensoriamento Remoto 4, 3653-3660.

Cruz, C.B.M., Barros, R.S.de, Cardoso, P.V., Reis, R.B., Rosario, L.S.do, Barbosa, S.dosS., Rabaco, L.M.L., Lourenço, J.S.deQ., 2011. Avaliação da exatidão planialtimétrica dos modelos digitais de superfície (MDS) e do terreno (MDT) obtidos através do LIDAR. XV Simpósio Brasileiro de Sensoriamento Remoto.

Dalmolin, Q., Leal, E.daM., 2001. Análise da qualidade posicional em bases cartográficas geradas em CAD. Boletim de Ciências Geodésicas 7, 21-40.

Daru, R.L., Silveira, R.M.da, Hainosz, F.S., Buras, M., 2013. Propagação de ondas de ruptura e plano de ações emergênciais-UHE Barra do Braúna. XX Simpósio Brasileiro de Recursos Hídricos.

Fazan, A.J., Dal Poz, A.P., 2010. Compensação de sombras de edifícios usando imagens aéreas de alta resolução e dados de varredura a laser. Revista Brasileira de Cartografia 62, 433-440.

FEMA. Federal Emergency Management Agency, 2010. Procedure Memorandum No. 61 - Standards for Lidar and Other High
Quality Digital Topography. Available: http://goo.gl/S8B6Zv. Access: aug., 20, 2014.

FGDC. Federal Geographic Data Committee, 1998. National Standard for Spatial Data Accuracy. Available: http://goo.gl/SLX7i6. Access: aug., 20, 2014.

Flood, M., 2001. Laser altimetry: from science to commercial LIDAR mapping. Photogrammetric Engineering \& Remote Sensing 67, 1209-1218.

Fowler, R., 2001. Topographic LIDAR, in: Maune, D.F. (Ed.), Digital Elevation Model Technologies and Applications: the DEM users manual. ASPRS, Bethesda.

Geissler, H.J., 2012. Avaliação de cenários de inundações no planejamento do uso e ocupação do solo urbano. Thesis (Doctoral). Florianópolis, UFSC.

Giongo, M., Koehler, H.S., Machado, S.A., Kirchner, F.F., Marchetti, M., 2010. LiDAR: princípios e aplicações florestais. Pesquisa Florestal Brasileira 30, 231-244.

Giongo, M., Koehler, H.S., Viola, M.R., Bastos, P.D.S., Santos, A.F.dos, Santopuoli, G., 2012. Estimativa da altura da base das copas com o uso de dados laser scanning aerotransportado (LIDAR). Journal of Biotechnology and Biodiversity 3, 48-57.

Graham, L., 2014. Entrevista concedida à Fugro EarthData's Newsletter - Perspectives. Available: http://goo.gl/JpDqr9. Access: sep., 17, 2014.

Guo, Q., Li, W., Yu, H., Alvarez, O., 2010. Effects of topographic variability and LIDAR sampling density on several DEM interpolation methods. Photogrammetric Engineering \& Remote Sensing 76, 701-712.

Heidemann, H.K., 2012. Lidar base specification version 1.0. US Geological Survey Techniques and Methods. Available: http://goo.gl/5wGJ4e. Access: sep., 19, 2014.

Hengl, T., 2006. Finding the right pixel size. Computers \& Geosciences 32, 1283-1298.

Heritage, G.L., Large, A.R.G. (Ed.), 2009. Laser Scanning for the Environmental Sciences. John Wiley \& Sons, Chichester.

Hetherington, D., 2009. Laser Scanning: data quality, protocols and general issues, in: Heritage, G.L., Large, A.R.G. (Ed.), Laser Scanning for the Environmental Sciences. John Wiley \& Sons, Chichester. 
Leal, P.R.G., 2007. Controle de qualidade em cartografia: proposta metodológica para avaliação das cartas topográficas do mapeamento sistemático nacional. Thesis (Master). Florianópolis, UFSC.

Lillesand, T., Kiefer, R., 2000. Remote Sensing and Image Interpretation. Wiley, New York.

Liu, X., 2008. Airborne LiDAR for DEM generation: some critical issues. Progress in Physical Geography 32, 31-49.

Macedo, R.deC., Santos, J.R.dos, Soares, J.V., 2013. Validação de modelo digital de terreno em área florestal com relevo ondulado, gerado a partir de dados LiDAR. Revista Brasileira de Cartografia 65, 695-702.

Marks, K., Bates, P., 2000. Integration of highresolution topographic data with floodplain flow models. Hydrological Processes 14, 2109-2122.

Meneses, P.R., Almeida, T., 2012. Introdução ao Processamento de Imagens de Sensoriamento Remoto. Universidade de Brasília, Brasília.

Minnesota Planning, 1999. Positional Accuracy Handbook: using the National Standard for Spatial Data Accuracy to measure and report geographic data quality. Minnesota Planning Land Management Information Center, St. Paul. Available: http://goo.gl/fX8ixw. Access: sep., 23, 2014.

NDEP. National Digital Elevation Program, 2004. Guidelines for Digital Elevation Data. Available: http://goo.gl/C0ntpe. Access: aug., 20, 2014.

NMAS. National Map Accuracy Standards, 1941. U.S. Bureau of the Budget. Available: http://goo.gl/nbxgzR. Access: sep., 19, 2014.

Negrón, R.A.R., 2002. Tecnologia Laser scanning e seu potencial de aplicação no mapeamento. Thesis (Master). Rio de Janeiro, IME.

NOAA. National Oceanic and Atmospheric Administration, 2004. Light Detection And Ranging (LIDAR) Requirements - Scope of work for shoreline mapping. Available: http://goo.gl/blJLc5. Access: aug., 20, 2014.

NOAA. National Oceanic and Atmospheric Administration, 2012. Lidar 101: An Introduction to Lidar Technology, Data, and Applications. National Oceanic and Atmospheric Administration (NOAA) Coastal Services Center, Charleston.
Pacheco, A.P., Centeno, J.A.S., Assunção, M.G.T.A., Botelho, M.F., 2011. Classificação de pontos LIDAR para a geração do MDT. Boletim de Ciências Geodésicas 17, 417-438.

Pereira, G.H.deA., 2013. Avaliação do uso combinado de métodos de modelagem da direção do escoamento superficial e modelos digitais de superficie derivados de laser scanner em regiões urbanas. Thesis (Master). Curitiba, UFPR.

Pereira, A., Gomes, A.A., Perez-Alberti, A., 2013. Vantagens da utilização de dados ALS (LIDAR) na caracterização morfológica das vertentes costeiras da Galiza (Espanha): aplicação ao setor de Mougás. Revista de Geografia e Ordenamento do Território 1, 223-248.

Pike, R.J., 2002. A bibliography of terrain modeling (geomorphometry), the quantitative representation of topography. USGS Open file report 02-465.

Ribas, R.P., Elmiro, M.A.T., 2013. Individualização de árvores em ambiente florestal nativo utilizando métodos de segmentação em modelos digitais produzidos a partir da tecnologia LIDAR. Revista Brasileira de Cartografia 65, 719-729.

Ribeiro Júnior, S., Vieira, C.A.O., 2013. Aplicação do processo analítico hierárquico na escolha de tecnologia de coleta de dados para cálculo de volume de minério estocado. Revista Brasileira de Cartografia 65, 633-641.

Rivas, R.A.N., Brito, J.L.N.S., 2003. A tecnologia "Laser Scanning": Uma alternativa para o mapeamento topográfico. XXI Congresso Brasileiro de Cartografia.

Rocha, R.dosS.da., 2002. Exatidão cartográfica para as cartas digitais urbanas. Thesis (Doctoral). Florianópolis, UFSC.

Sangster, C., 2002. Validating LiDAR Evaluating LiDAR Accuracy Using GPS. Applied Geomatics Research Group, Centre of Geographic Science, Lawrencetown.

Santos, S.D.R., Huinca, S.C.M., Melo, L.F.D.S., Da Silva, M.T.Q.S., Delazari, L.S., 2010. Considerações sobre a utilização do PEC (Padrão de Exatidão Cartográfica) nos dias atuais. III Simpósio Brasileiro de Ciências Geodésicas e Tecnologias da Geoinformação.

SBSR. Biblioteca Digital - SBSR, 2015. INPE. Available: http://goo.gl/eapHPJ. Access: aug., 20, 2016. 
Schafer, A.G., Loch, R.E.N., 2005. Aplicação do sensoriamento remoto em projetos rodoviários: um histórico, uma realidade e uma necessidade como disciplina em cursos de engenharia. XII Simpósio Brasileiro de Sensoriamento Remoto, 1361-1368.

Schimalesky, V., 2007. Avaliação da qualidade da informação altimétrica derivada da varredura a LASER em uma região coberta por vegetação: um estudo de caso. Thesis (Doctoral). Curitiba, UFPR.

Schuch, F.S., Loch, C., 2012. Determinando a variação do padrão fractal de rede de drenagem utilizando dados SRTM, laser scanning e base cartográfica. Revista Brasileira de Cartografia.

Schuckman, K., 2014. Entrevista concedida à Fugro EarthData's Newsletter - Perspectives. Available: http://goo.gl/r1fw1Y. Access: sep., 17, 2014.

Sloboda, L., 2005. Proposta metodológica para confecção de base cartográfica a partir de dados oriundos do Sistema Laser Scanner. Thesis (Master). Florianópolis, UFSC.

Soares, L.D.V., 2010. Avaliação do sistema cartográfico municipal. Thesis (Master). Florianópolis, UFSC.

Sopchaki, C.H., 2016. Influência do n amostral e das características do relevo na qualidade de modelos digitais do terreno. Thesis (Doctoral). Curitiba, UFPR.

Su, J., Bork, E., 2006. Influence of vegetation, slope, and lidar sampling angle on DEM accuracy. Photogrammetric Engineering \& Remote Sensing 72, 1265-1274.

Sumerling, G., 2011. Lidar Analysis in ArcGIS 10 for Forestry Applications. PDF white paper. ESRI Inc 1, 1-53.

USACE. U.S. Army Corps of Engineers, 2002. Engineering and Design - Photogrammetric Mapping. Available: http://goo.gl/jvXnLg. Access: aug., 20, 2014.

U.S. Bureau of the Budget, 1941. United States National Map Accuracy Standards. Available: http://goo.gl/nbxgzR. Access: sep., 19, 2014.

Wack, R., Wimmer, A., 2002. Digital Terrain Models from Airborne LASER Scanner Data - A grid based approach. International Archives of Photogrammetry. Remote Sensing 34(B3), 293-296. 